\author{
Anna Żyła \\ Politechnika Świętokrzyska \\ e-mail: azyla@tu.kielce.pl
}

\title{
ANALIZA POZIOMU ROZWOJU SPOLECZNO- -GOSPODARCZEGO KRAJÓW AZJI WSCHODNIEJ Z ZASTOSOWANIEM TAKSONOMICZNEGO MIERNIKA ROZWOJU HELLWIGA
}

\section{THE ANALYSIS OF THE LEVEL OF SOCIO- -ECONOMIC DEVELOPMENT OF EAST ASIAN COUNTRIES USING HELLWIG'S TAXONOMIC MEASURE OF DEVELOPMENT}

DOI: $10.15611 /$ pn.2018.523.36

JEL Classification: O530, O470, O110, O150, F630, E660

Streszczenie: Rosnące znaczenie gospodarek azjatyckich na arenie międzynarodowej w ciągu ostatnich kilkudziesięciu lat jest faktem niezaprzeczalnym. Celem niniejszego artykułu było zbadanie poziomu rozwoju społeczno-ekonomicznego siedemnastu gospodarek należących do szeroko pojętego regionu Azji Wschodniej. Analiza przeprowadzona została na podstawie taksonomicznego miernika rozwoju Hellwiga z wykorzystaniem dwudziestu trzech zmiennych diagnostycznych. W celu porównania pozycji osiąganych przez poszczególne gospodarki w regionie w ciągu lat do pomiaru wykorzystano dane statystyczne z 2007 i 2016 roku. Badanie potwierdziło bardzo dużą dysproporcję w rozwoju społeczno-gospodarczym krajów regionu. Do zdecydowanych liderów zaliczyć można tutaj: Singapur oraz Hongkong, natomiast do krajów najsłabiej rozwiniętych Mjanmę oraz Timor Wschodni. Jednocześnie należy zaznaczyć, że badanie nie obejmowało Korei Północnej i Tajwanu ze względu na trudność w uzyskaniu danych statystycznych dla tych państw.

Słowa kluczowe: rozwój społeczno-gospodarczy, Azja Wschodnia, taksonomiczny miernik rozwoju Hellwiga.

Summary: The growing importance of Asian economies in the international arena over the past few decades is undeniable. The purpose of this article was to examine the level of socioeconomic development of seventeen economies belonging to the East Asian region. The analysis was based on the Hellwig's taxonomic measure of development using twenty-three diagnostic features. In order to compare the positions achieved by individual economies in the region over the years, the statistical data from 2007 and 2016 were used for the measurement. The study confirmed a large disproportion in the socio-economic development of analysed countries. The leaders in the region are Singapore and Hong Kong, while the least developed 
countries are Myanmar and East Timor. At the same time, it should be noted that the study did not include North Korea and Taiwan because of the difficulty in obtaining statistical data for these countries.

Keywords: socio-economic development, East Asia, Hellwig's taxonomic measure of development.

\section{Wstęp}

W ciągu ostatnich kilku dekad w strukturze geograficznej gospodarki globalnej zaszło wiele znaczących zmian. Wśród najważniejszych niewątpliwie wymienić należy wzrost znaczenia krajów azjatyckich w kształtowaniu stosunków międzynarodowych, determinowany szybko postępującym rozwojem społeczno-ekonomicznym tych państw. Ten $\mathrm{z}$ kolei jest $\mathrm{w}$ ogromnej mierze pochodną procesów internacjonalizacji działalności gospodarczej. Istotne jest przy tym obserwowane w ostatnich kilkunastu latach zmniejszenie roli Japonii zaliczanej wcześniej wraz ze Stanami Zjednoczonymi i Unią Europejską do gospodarczej „triady” świata. Jest to wynikiem stagnacji, jaką kraj ten przechodzi od lat 90. XX wieku. Biorąc pod uwage powyższe, należy stwierdzić, że ciągła potrzeba badania rozmiarów i dynamiki rozwoju krajów azjatyckich wydaje się konieczna i uzasadniona.

Celem artykułu jest zbadanie poziomu rozwoju społeczno-ekonomicznego gospodarek należących do regionu Azji Wschodniej. Jest on bez wątpienia zaliczany do najprężniej rozwijających się gospodarczo obszarów świata. Autorka zaliczyła do niego następujące kraje: Chiny, Hongkong, Mongolię, Japonię, Koreę Południową, Koreę Północną, Tajwan, Timor Wschodni oraz kraje należące do ASEAN (Singapur, Indonezję, Malezję, Filipiny, Tajlandię, Brunei, Laos, Wietnam, Kambodżę oraz Mjanmę). Realizacja wskazanego celu możliwa była przede wszystkim dzięki wykorzystaniu metod matematycznych (badanie przeprowadzone zostało z wykorzystaniem taksonomicznego miernika rozwoju Hellwiga) oraz metody porównawczej. Niestety dokonanie kompleksowej analizy w stosunku do wszystkich wymienionych krajów okazało się niemożliwe. Ze względu na trudności ze zgromadzeniem danych już na pierwszym etapie badania wykluczono Koreę Północną oraz Tajwan. W obu przypadkach wpływ na taki stan rzeczy ma sytuacja polityczna tych państw. We wszystkich raportach organizacji międzynarodowych publikujących kompleksowe dane statystyczne dotyczące poszczególnych krajów informacje na temat Korei Północnej mają charakter wybiórczy, jeśli chodzi zarówno o liczbę badanych wskaźników, jak i przekrój czasowy analizy. Z kolei dane dotyczące Tajwanu wliczane są do wyników osiąganych przez Chiny ze względu na fakt, że Tajwan nie jest traktowany jako kraj autonomiczny przez znaczącą większość państw na świecie. Dodatkowo przeprowadzona w niniejszym artykule analiza uzupełniona została o Indie, uznawane przez wielu badaczy za wschodzącego ,azjatyckiego 
tygrysa", którego rola w kształtowaniu stosunków na kontynencie w ciągu najbliższych kilku dekad znacznie wzrośnie.

\section{Opis zastosowanej metody badawczej}

Taksonomiczny miernik rozwoju Z. Hellwiga jest jedną z metod statystyczno-ekonometrycznej oceny uwarunkowań rozwoju badanych obszarów. Był on wielokrotnie wykorzystywany przez badaczy, także w odniesieniu do krajów azjatyckich. Niniejsza analiza przeprowadzona została jednak na większą niż dotychczas skalę, tzn. obejmuje aż siedemnaście państw oraz dwadzieścia trzy wskaźniki (cechy, zmienne diagnostyczne). Ponadto, nawiązując do informacji zawartych we wstępie, należy podkreślić, jak istotny jest zakres czasowy analizy, który objął lata 2007 i 2016. Okresy te wybrano nieprzypadkowo. Celem autorki było porównanie wyników badań przeprowadzonych na podstawie najbardziej aktualnych, dostępnych $\mathrm{w}$ chwili przeprowadzania badania danych z wynikami, jakie osiągały kraje regionu Azji Wschodniej tuż przed światowym kryzysem gospodarczym.

Budowa taksonomicznego miernika rozwoju przeprowadzona została w kilku etapach, które zostaną pokrótce omówione.

\subsection{Dobór zmiennych diagnostycznych}

Rozwój gospodarczy, rozwój społeczny, warunki życia, postęp techniczny, poziom rozwoju infrastruktury to przykłady zjawisk, których nie można zmierzyć za pomocą jednego wskaźnika. Metoda zaproponowana przez Hellwiga polega na zbudowaniu syntetycznego miernika, dzięki któremu możliwe jest zbadanie stopnia oddziaływania na rozwój społeczno-gospodarczy wielu różnych wskaźników jednocześnie [Hellwig 1968, s. 323-326]. Niezwykle istotny jest zatem sposób doboru zmiennych. Od nich zależeć będzie bowiem wynik osiągnięty przez analizowaną jednostkę.

W niniejszym badaniu wybór cech diagnostycznych poprzedzony został krytycznym przeglądem literatury odnoszącej się do pomiaru rozwoju społecznego i gospodarczego różnych obszarów. Wskaźniki wyselekcjonowane z uwzględnieniem kryteriów merytorycznych poddano w dalszym etapie ocenie pod względem kryteriów formalnych. Konstrukcja taksonomicznego miernika rozwoju Hellwiga wymaga bowiem wykorzystania jedynie tych zmiennych, które są dostępne, mają charakter mierzalny oraz są kompletne w analizowanym okresie. Ponadto, biorąc pod uwagę często spotykane różnice w wynikach badań przeprowadzanych przez różne instytucje lub organizacje o charakterze międzynarodowym oraz krajowym, odnoszące się do tych samych obszarów (co jest pochodną różnic w przyjętej metodologii badań), autorka zadbała o to, aby dane dotyczące jednej cechy były porównywalne i pochodziły dla wszystkich krajów zawsze z tego samego źródła. Na tej podstawie wyodrębniono dwadzieścia trzy zmienne, które zaprezentowano w tab. 1. 
Tabela 1. Zestaw zmiennych diagnostycznych przyjętych do badania poziomu rozwoju społeczno-gospodarczego krajów Azji Wschodniej

\begin{tabular}{|c|l|}
\hline Symbol zmiennej & \multicolumn{1}{|c|}{ Nazwa zmiennej diagnostycznej } \\
\hline$X_{1}$ & liczba ludności na 1 km² powierzchni \\
\hline$X_{2}$ & wskaźnik urbanizacji (udział ludności mieszkającej na obszarach miejskich w \%) \\
\hline$X_{3}$ & śmiertelność niemowląt na 1000 urodzeń żywych \\
\hline$X_{4}$ & oczekiwana długość życia w latach \\
\hline$X_{5}$ & wydatki na opiekę zdrowotną w relacji do PKB w \% \\
\hline$X_{6}$ & przewidywana liczba lat spędzanych w placówkach edukacyjnych \\
\hline$X_{7}$ & wskaźnik migracji netto na 1000 mieszkańców \\
\hline$X_{8}$ & stopa bezrobocia w \% \\
\hline$X_{9}$ & stopa bezrobocia wśród osób w wieku 15-24 lata w \% \\
\hline$X_{10}$ & wskaźnik aktywności zawodowej (udział ludności w wieku 15 lat i więcej \\
\hline$X_{11}$ & aktywnych zawodowo w \%) \\
\hline$X_{12}$ & PKBnamika wzrostu PKB w \% capita według parytetu siły nabywczej w dol. \\
\hline$X_{13}$ & wartość eksportu w relacji do PKB w \% \\
\hline$X_{14}$ & stan bilansu handlowego w relacji do PKB w \% \\
\hline$X_{15}$ & udział sektora usług w tworzeniu PKB w \% \\
\hline$X_{16}$ & wartość napływu bezpośrednich inwestycji zagranicznych netto w mld dol. \\
\hline$X_{17}$ & stopa inflacji w \% \\
\hline$X_{18}$ & wielkość deficytu budżetowego w relacji do PKB w \% \\
\hline$X_{19}$ & $\begin{array}{l}\text { wskaźnik korupcji (liczba z przedziału 1-100, gdzie 1 oznacza największe sko- } \\
\text { rumpowanie, a 100 oznacza kraj wolny od korupcji) }\end{array}$ \\
\hline$X_{10}$ & liczba telefonów komórkowych na 100 mieszkańców \\
\hline$X_{21}$ & udział ludności korzystającej z Internetu w \% \\
\hline$X_{22}$ & udział ludności posiadającej dostęp do elektryczności w \% \\
\hline$X_{23}$ & emisja CO na 1 mieszkańca w tonach metrycznych \\
\hline &
\end{tabular}

Źródło: opracowanie własne.

Ostatnim krokiem na etapie doboru zmiennych diagnostycznych do budowy taksonomicznego miernika rozwoju społeczno-gospodarczego krajów Azji Wschodniej było przeprowadzenie ich oceny pod względem kryteriów statystycznych [Obrębalski 2006, s. 33]. Jej wynikiem było wyodrębnienie spośród cech wskazanych w tab. 1 tzw. mierników-reprezentantów. W celu ustalenia poszukiwanego zbioru w pierwszej kolejności dokonano eliminacji zmiennych quasi-stałych. Dla każdej zmiennej obliczono współczynnik zmienności, który obrazuje stopień jej zróżnicowania. Klasyczny współczynnik zmienności wyznacza się jako stosunek odchylenia standardowego badanej zmiennej do wartości jej średniej arytmetycznej dla wszystkich analizowanych obiektów [Panek (red.) 2007, s. 120] (w tym przypadku krajów Azji Wschodniej). Wzór ma zatem postać:

$$
V_{j}=\frac{S_{j}}{\bar{x}_{j}}
$$


gdzie: $S_{j}$ - odchylenie standardowe dla $j$-tej cechy - wyznaczane jest jako pierwiastek z wariancji obliczanej według wzoru:

$$
S_{j}^{2}=\frac{1}{n} \sum_{i=1}^{n}\left(x_{i j}-\bar{x}_{j}\right)^{2},
$$

$\bar{x}_{j}-$ średnia arytmetyczna j-tej cechy obliczana według wzoru:

$$
\bar{x}_{j}=\frac{1}{n} \sum_{i=1}^{n} x_{i j}(\text { dla } i=1, \ldots, n) .
$$

Eliminacji zmiennych quasi-stałych (czyli tych, które nie wnoszą istotnych informacji o badanym zjawisku) dokonuje się poprzez odrzucenie ze zbioru tych cech, dla których wartość bezwzględna współczynnika zmienności nie przekracza wartości krytycznej, za którą przyjmuje się 0,1 . Wśród wskaźników wymienionych w tab. 1 tylko jedna spełniała powyższy warunek i została wyeliminowana na tym etapie. Była to zmienna $X_{4}$ - oczekiwana długość życia w latach.

Drugim elementem oceny cech diagnostycznych pod względem kryteriów statystycznych była eliminacja zmiennych silnie skorelowanych. Badanie siły związku pomiędzy zmiennymi wykonano przy wykorzystaniu współczynnika korelacji liniowej Pearsona [Wasilewska 2011, s. 285-292]. Oblicza się go według wzoru:

$$
r_{x y}=\frac{\sum_{i=1}^{n}\left(x_{i}-\bar{x}\right)\left(y_{i}-\bar{y}\right)}{\sqrt{\sum_{i=1}^{n}\left(x_{i}-\bar{x}\right)^{2} \sum_{i=1}^{n}\left(y_{i}-\bar{y}\right)^{2}}},
$$

gdzie: $x, y$-mierzalne cechy statystyczne; $\bar{x}, \bar{y}$ - średnia arytmetyczna cech $x$ i $y$.

Eliminacji zmiennych silnie skorelowanych dokonuje się przez odrzucenie ze zbioru tych cech, dla których wartość bezwzględna współczynnika korelacji liniowej Pearsona przekracza wartość krytyczną, za którą przyjęto 0,7. Ostatecznie na tym etapie wyeliminowano $\mathrm{z}$ dalszego badania pięć kolejnych cech: $X_{1}-$ liczba ludności na $1 \mathrm{~km}^{2}$ powierzchni, $X_{2}$ - wskaźnik urbanizacji, $X_{6}$ - przewidywana liczba lat spędzanych w placówkach edukacyjnych, $X_{19}$ - wskaźnik korupcji oraz $X_{23}$ - emisja $\mathrm{CO}_{2}$ na 1 mieszkańca w tonach metrycznych. Należy przy tym zaznaczyć, że wyeliminowane zmienne wykazywały bardzo silną korelację z co najmniej czterema innymi cechami. W badaniu pojawiły się także pojedyncze zmienne, które wykazywały silną korelację z jedną cechą, jednakże ze względu na ich duże znaczenie merytoryczne zostały uwzględnione $\mathrm{w}$ dalszej analizie.

Otrzymany zbiór zmiennych diagnostycznych, który posłużył do budowy taksonomicznego miernika rozwoju, zawierał zatem siedemnaście cech. Wartości badanych zmiennych w latach 2007 i 2016 zaprezentowano w tab. 2 i 3. 
Tabela 2. Wartości zmiennych diagnostycznych z roku 2007 uwzględnionych w budowie taksonomicznego miernika rozwoju

\begin{tabular}{|c|c|c|c|c|c|c|c|c|c|c|c|c|c|c|c|c|c|}
\hline Kraj & $X_{3}$ & $X_{5}$ & $X_{7}$ & $\mathrm{X}_{8}$ & $\mathrm{X}_{9}$ & $X_{10}$ & $X_{11}$ & $X_{12}$ & $\mathrm{X}_{13}$ & $\mathrm{X}_{14}$ & $X_{15}$ & $X_{16}$ & $X_{17}$ & $\mathrm{X}_{18}$ & $X_{20}$ & $X_{21}$ & $X_{22}$ \\
\hline Brunei & 13,1 & 2,3 & 2,8 & 5,7 & 6,5 & 66,9 & 0,2 & 79617 & 67,9 & 41,0 & 28,0 & 258 & 1,0 & $-3,1$ & 96 & 53,3 & 100 \\
\hline Chiny & 22,1 & 4,3 & $-0,4$ & 3,8 & 9,3 & 73,5 & 14,2 & 6864 & 35,9 & 7,4 & 42,9 & 156249 & 4,8 & $-0,1$ & 41 & 19,2 & 98 \\
\hline Hong Kong & 2,9 & 4,8 & 4,7 & 4,0 & 10,7 & 60,9 & 6,5 & 43281 & 186,4 & $-9,8$ & 92,9 & 62121 & 2,0 & $-7,3$ & 155 & 56,7 & 100 \\
\hline Indonezja & 32,1 & 3,1 & $-1,8$ & 9,1 & 32,3 & 67,6 & 6,3 & 7020 & 27,6 & 5,4 & 39,4 & 6928 & 6,4 & 1 & 40 & 5,5 & 91 \\
\hline Indie & 34,4 & 4,2 & $-0,1$ & 3,7 & 9,9 & 60,6 & 9,8 & 3485 & 21 & $-6,6$ & 46,4 & 25228 & 6,4 & 4,5 & 20 & 7,1 & 69 \\
\hline Japonia & 2,8 & 8,3 & 0,0 & 3,9 & 8,7 & 60,5 & 1,7 & 34502 & 17,5 & 2,1 & 69,1 & 21631 & 0,1 & 2,8 & 84 & 69,1 & 100 \\
\hline Kambodża & 58,5 & 3,8 & 0,0 & 0,9 & 1,6 & 80,9 & 10,2 & 2198 & 65,3 & $-15,7$ & 40,6 & 867 & 7,7 & $-0,7$ & 19 & 0,5 & 30 \\
\hline Korea Południowa & 6,1 & 6,0 & 0,0 & 3,2 & 10,1 & 60,9 & 5,5 & 27823 & 39,2 & 1,3 & 60,3 & 8827 & 2,5 & $-2,2$ & 93 & 72,6 & 100 \\
\hline Laos & 81,4 & 4,1 & 0,0 & 1,4 & 3,2 & 78,8 & 7,6 & 3317 & 33,6 & -3 & 37 & 324 & 4,5 & 2,7 & 25 & 1,5 & 60 \\
\hline Mjanma & 50,7 & 1,7 & 0,0 & 0,8 & 13,2 & 78,0 & 12 & 2676 & 33,2 & 12,9 & 36,3 & 710 & 35 & 3,1 & 0 & 0,1 & 49 \\
\hline Mongolia & 42,7 & 5,1 & 0,0 & 7,2 & 13,6 & 60,3 & 10,2 & 6647 & 59,6 & $-4,3$ & 37,7 & 373 & 9,0 & $-7,1$ & 46 & 10,8 & 79 \\
\hline Malezja & 16,6 & 3,6 & 0,0 & 3,2 & 11 & 61,2 & 9,4 & 19488 & 106,2 & 15,4 & 47,8 & 9071 & 2,0 & 3,2 & 87 & 63,9 & 98 \\
\hline Filipiny & 22,1 & 3,9 & $-1,5$ & 7,4 & 16,9 & 64,9 & 6,6 & 4881 & 43,3 & -5 & 54,5 & 2919 & 2,9 & 1,4 & 65 & 5,8 & 81 \\
\hline Singapur & 2,3 & 3,5 & 8,0 & 3,9 & 8,5 & 64,9 & 9,1 & 64466 & 214,8 & 20,1 & 70,6 & 47733 & 2,1 & $-11,2$ & 125 & 68,2 & 100 \\
\hline Tajlandia & 18,9 & 3,6 & 0,0 & 1,2 & 4,7 & 73,6 & 5,4 & 11878 & 68,9 & 5,3 & 51,1 & 8634 & 2,2 & 0,3 & 80 & 20,6 & 94 \\
\hline Timor Wschodni & 43,0 & 0,4 & 0,0 & 6,7 & 15,7 & 49,3 & 11,4 & 1176 & 98,9 & $-6,4$ & 64,2 & 9 & 10,3 & 40,9 & 8 & 0,1 & 37 \\
\hline Wietnam & 24,4 & 6,1 & $-0,4$ & 2,4 & 4,4 & 77 & 7,1 & 3610 & 70,5 & $-18,2$ & 38,2 & 6700 & 8,3 & 5,0 & 52 & 21 & 94 \\
\hline
\end{tabular}

(04.03.2018); World Development Indicators, The World Bank, https://data.world bank.org/indicator (04.03.2018); https://coun tryeconomy.

com/ (04.03.2018); Human Development Data, UNDP, http://hdr.undp.org/en/data (04.03.2018); https:/www.indexmun di.com/ (04.03.2018);

United Nations Data, http://data.un.org/ (04.03.2018). 
Tabela 3. Wartości zmiennych diagnostycznych z roku 2016 uwzględnionych w budowie taksonomicznego miernika rozwoju

\begin{tabular}{|c|c|c|c|c|c|c|c|c|c|c|c|c|c|c|c|c|c|}
\hline Kraj & $X_{3}$ & $X_{5}$ & $X_{7}$ & $\mathrm{X}_{8}$ & $\mathrm{X}_{9}$ & $X_{10}$ & $X_{11}$ & $X_{12}$ & $X_{13}$ & $\mathrm{X}_{14}$ & $X_{15}$ & $X_{16}$ & $X_{17}$ & $\mathrm{X}_{18}$ & $X_{20}$ & $X_{21}$ & $X_{22}$ \\
\hline Brunei & 9,9 & 2,6 & 2,4 & 6,5 & 5,7 & 63,5 & $-2,5$ & 77421,0 & 49,6 & 16,4 & 41,5 & $-151,0$ & $-0,7$ & 21,6 & 121,0 & 71,2 & 100,0 \\
\hline Chiny & 2,2 & 5,5 & $-0,4$ & 4,6 & 12,1 & 70,9 & 6,7 & 15529,0 & 19,6 & 4,6 & 51,6 & 70557,0 & 2,0 & 4,0 & 97,0 & 53,2 & 100,0 \\
\hline Hongkong & 2,7 & 5,3 & 1,7 & 3,4 & 9,5 & 60,3 & 2,0 & 58618,0 & 187,4 & $-9,5$ & 92,2 & 117110,0 & 2,4 & $-1,0$ & 234,0 & 85,0 & 100,0 \\
\hline Indonezja & 3,5 & 2,8 & $-1,1$ & 5,6 & 19,3 & 67,4 & 5,0 & 11609,0 & 19,1 & 1,0 & 45,3 & 4142,0 & 3,5 & 2,4 & 149,0 & 25,4 & 97,0 \\
\hline Indie & 0,5 & 4,7 & 0,0 & 3,5 & 9,7 & 53,7 & 7,1 & 6571,0 & 19,2 & $-4,2$ & 53,8 & 44459,0 & 4,9 & 3,3 & 87,0 & 29,5 & 79,2 \\
\hline Japonia & 2,0 & 10,2 & 0,0 & 3,1 & 5,3 & 59,3 & 1,0 & 42203,0 & 16,1 & 0,8 & 70,0 & 34905,0 & $-0,1$ & 4,6 & 130,0 & 92,0 & 100,0 \\
\hline Kambodża & 8,7 & 5,7 & $-0,3$ & 0,2 & 0,8 & 80,9 & 7,0 & 3737,0 & 61,3 & $-12,7$ & 41,6 & 2287,0 & 3,0 & 1,9 & 125,0 & 25,6 & 56,1 \\
\hline Korea Południowa & 3,0 & 7,4 & 2,5 & 3,7 & 10,4 & 60,8 & 2,8 & 36532,0 & 42,2 & 6,3 & 59,2 & 10827,0 & 1,0 & $-0,9$ & 123,0 & 89,9 & 100,0 \\
\hline Laos & 1,4 & 1,9 & $-1,1$ & 1,4 & 4,0 & 77,4 & 7,0 & 6550,0 & 35,1 & $-10,8$ & 48,0 & 997,0 & 1,5 & 5,6 & 55,0 & 18,2 & 78,1 \\
\hline Mjanma & 2,2 & 2,3 & $-1,5$ & 0,8 & 12,1 & 78,0 & 5,9 & 5721,0 & 17,4 & $-8,7$ & 39,5 & 3278,0 & 7,0 & 3,3 & 89,0 & 25,1 & 52,0 \\
\hline Mongolia & 1,8 & 4,7 & $-0,8$ & 6,8 & 14,7 & 62,5 & 1,2 & 12252,0 & 50,2 & 14,1 & 50,5 & $-4156,0$ & 0,6 & 10,0 & 114,0 & 22,3 & 85,6 \\
\hline Malezja & 2,9 & 4,2 & $-0,3$ & 3,5 & 10,4 & 63,3 & 4,2 & 27683,0 & 67,7 & 7,1 & 53,0 & 13516,0 & 2,1 & 2,9 & 141,0 & 78,8 & 100,0 \\
\hline Filipiny & 1,9 & 4,7 & $-2,0$ & 5,5 & 15,7 & 64,7 & 6,9 & 7804,0 & 28,0 & $-9,8$ & 59,5 & 7980,0 & 1,8 & 2,7 & 109,0 & 55,5 & 89,1 \\
\hline Singapur & 2,4 & 4,9 & 13,1 & 1,8 & 7,3 & 67,2 & 2,0 & 87833,0 & 172,1 & 15,8 & 73,8 & 61597,0 & $-0,5$ & 1,0 & 147,0 & 81,0 & 100,0 \\
\hline Tajlandia & 9,4 & 4,1 & 0,0 & 0,9 & 4,7 & 71,4 & 3,2 & 16913,0 & 68,9 & 5,1 & 55,8 & 3063,0 & 0,2 & 2,5 & 173,0 & 47,5 & 100,0 \\
\hline Timor Wsc & 36,3 & 1,5 & $-3,9$ & 3,8 & 15,7 & 41,3 & 5,7 & 2140,0 & 62,2 & $-42,6$ & 63,6 & 5,0 & $-1,2$ & 70,0 & 125,0 & 25,2 & 45,4 \\
\hline Wietnam & 17,8 & 7,1 & $-0,3$ & 2,2 & 5,3 & 78,3 & 6,2 & 6296,0 & 93,6 & 1,3 & 45,5 & 12600,0 & 3,2 & 5,4 & 128,0 & 52,7 & 99,2 \\
\hline
\end{tabular}

Źródło: opracowanie własne na podstawie: The World Factbook 2016, 2017, op.cit. (04.03.2018); World Development Indicators, op.cit. (04.03.2018); https://coun tryeconomy.com/ (04.03.2018); Human Development Data, op.cit. (04.03.2018); https://www.indexmun di.com/ (04.03.2018); United Nations Data, op.cit. (04.03.2018). 


\subsection{Konstrukcja taksonomicznego wzorca rozwoju}

Opisany powyżej proces, czyli dobór zmiennych diagnostycznych, jest najbardziej czasochłonnym etapem przeprowadzonego badania ze względu na trudność uzyskania odpowiednich danych statystycznych. Punktem wyjścia dla etapu drugiego było stworzenie macierzy obserwacji ze wszystkich cech, które pozostały po eliminacji zmiennych quasi-stałych i zmiennych silnie skorelowanych. Wspomniana macierz obserwacji ma postać:

$$
\mathbf{X}=\left[\begin{array}{cccc}
x_{11} & x_{12} & \cdots & x_{1 m} \\
x_{21} & x_{22} & \cdots & x_{2 m} \\
\cdots & \cdots & \cdots & \cdots \\
x_{n 1} & x_{n 2} & \cdots & x_{n m}
\end{array}\right],
$$

gdzie: $x_{i j}$ - wartość $j$-tej cechy dla $i$-tego obiektu (kraju Azji Wschodniej).

Jednym z najważniejszych elementów przeprowadzanej analizy była standaryzacja cech, czyli doprowadzenie zmiennych różnoimiennych do stanu porównywalności [Panek (red.) 2007, s. 121]. Czynności tej dokonuje się, opierając się na następującym wzorze:

$$
z_{i j}=\frac{x_{i j}-\bar{x}_{j}}{S_{j}},
$$

gdzie: $x_{i j}$ - wyjściowa wartość $j$-tej cechy dla $i$-tego obiektu (kraju Azji Wschodniej); $z_{i j}$-standaryzowana wartość $j$-tej cechy dla $i$-tego obiektu (kraju Azji Wschodniej); $m$ - liczba cech; $n$ - liczba obiektów (krajów Azji Wschodniej).

W wyniku przeprowadzonych przekształceń powstała macierz standaryzowana $\mathrm{Z}$, analogiczna do pierwotnej macierzy obserwacji X, jednak zawierająca wartości cech po ich normalizacji.

Kolejnym krokiem było określenie kierunku oddziaływania poszczególnych cech na badane zjawisko. Cechy, dla których pożądane są wartości jak najwyższe, nazywane są stymulantami, tymczasem cechy, dla których pożądane są wartości jak najniższe, nazywane są destymulantami [Hellwig 1968, s. 323-326]. Przeprowadzając analizę poziomu rozwoju społeczno-gospodarczego krajów Azji Wschodniej, autorka do stymulant zaliczyła cechy: $X_{5}, X_{7}, X_{10}, X_{11}, X_{12}, X_{13}, X_{14}, X_{15}, X_{16}, X_{20}, X_{21}$ oraz $X_{22}$, a do destymulant cechy: $X_{3}, X_{8}, X_{9}, X_{17}$ oraz $X_{18}$.

Budowa taksonomicznego wzorca rozwoju polegała na stworzeniu modelowego, abstrakcyjnego obiektu (kraju), który charakteryzował się najkorzystniejszymi wartościami wszystkich zmiennych. Wartości te ustalono w następujący sposób:

- $\quad$ w przypadku każdej stymulanty wybrano maksymalną wartość zmiennej zaobserwowanej wśród badanych siedemnastu krajów Azji Wschodniej,

- w przypadku każdej destymulanty wybrano minimalną wartość zaobserwowanej zmiennej. 


\subsection{Obliczenie wartości taksonomicznego miernika rozwoju Hellwiga dla krajów Azji Wschodniej}

Ostatnim etapem przeprowadzonego badania było stworzenie syntetycznego wskaźnika rozwoju społeczno-gospodarczego krajów Azji Wschodniej.

W pierwszej kolejności dokonano pomiaru tzw. odległości euklidesowych pomiędzy badanymi krajami a krajem modelowym stworzonym w poprzednim etapie. Do obliczenia odległości euklidesowych wykorzystano następujący wzór [Stec 2011, s. 235-236]:

$$
d_{i 0}=\sqrt{\sum_{j=1}^{m}\left(z_{i j}-z_{0 j}\right)^{2}},
$$

gdzie: $z_{0 j}$ - standaryzowana wartość $j$-tej cechy dla wzorca.

Miarę rozwoju stanowi wartość odpowiadająca poniższej formule:

$$
d_{i}=1-\frac{d_{i 0}}{d_{0}}
$$

gdzie: $d_{0}$ - krytyczna odległość danego obiektu od wzorca, obliczana według wzoru:

$$
d_{0}=\bar{d}_{0}-2 S_{0},
$$

$\bar{d}_{0}$ - średnia arytmetyczna wartości euklidesowych, obliczana według wzoru:

$$
\bar{d}_{0}=\frac{1}{n} \sum_{i=1}^{n} d_{i 0}(\mathrm{dla} i=1, \ldots, n),
$$

$S_{0}$ - odchylenie standardowe wartości euklidesowych, obliczane według wzoru:

$$
S_{0}=\sqrt{\frac{1}{n} \sum_{i=1}^{n}\left(d_{i 0}-\bar{d}_{0}\right)^{2}} .
$$

Wartości wskaźników $d_{i}$ stanowiących wynik niniejszego badania mieszczą się w przedziale [0,1]. Im wyższe wartości, tym kraj jest uznawany za wyżej rozwinięty.

\section{Interpretacja uzyskanych wyników}

Wykorzystując taksonomiczny miernik rozwoju Hellwiga, można było stworzyć ranking krajów Azji Wschodniej według stopnia ich rozwoju. Rezultaty badania przedstawiono w tab. 4. 
Tabela 4. Ranking krajów Azji Wschodniej ze względu na taksonomiczny miernik rozwoju społeczno-gospodarczego

\begin{tabular}{|c|c|c|c|c|c|}
\hline \multirow[t]{2}{*}{ Lp. } & \multicolumn{2}{|c|}{ Rok 2007} & \multirow[t]{2}{*}{ Lp. } & \multicolumn{2}{|c|}{ Rok 2016} \\
\hline & Kraj & Wartość miernika $d_{i}$ & & Kraj & Wartość miernika $d$ \\
\hline 1 & Singapur & 0,5902 & 1 & Singapur & 0,6057 \\
\hline 2 & Hongkong & 0,5061 & 2 & Hongkong & 0,5283 \\
\hline 3 & Malezja & 0,3604 & 3 & Japonia & 0,4014 \\
\hline 4 & Chiny & 0,3590 & 4 & Korea Południowa & 0,3876 \\
\hline 5 & Korea Południowa & 0,3492 & 5 & Tajlandia & 0,3841 \\
\hline 6 & Japonia & 0,3327 & 6 & Wietnam & 0,3531 \\
\hline 7 & Tajlandia & 0,3256 & 7 & Malezja & 0,3457 \\
\hline 8 & Brunei & 0,3056 & 8 & Chiny & 0,3290 \\
\hline 9 & Wietnam & 0,2558 & 9 & Brunei & 0,2556 \\
\hline 10 & Indie & 0,2200 & 10 & Kambodża & 0,2403 \\
\hline 11 & Mongolia & 0,2143 & 11 & Filipiny & 0,2317 \\
\hline 12 & Filipiny & 0,2033 & 12 & Indie & 0,2055 \\
\hline 13 & Laos & 0,1805 & 13 & Mongolia & 0,2038 \\
\hline 14 & Kambodża & 0,1784 & 14 & Indonezja & 0,1778 \\
\hline 15 & Indonezja & 0,1145 & 15 & Laos & 0,1629 \\
\hline 16 & Mjanma & 0,1119 & 16 & Mjanma & 0,1046 \\
\hline 17 & Timor Wschodni & 0,0398 & 17 & Timor Wschodni & 0,0128 \\
\hline
\end{tabular}

Źródło: opracowanie własne.

Z przeprowadzonego badania wynika, że zarówno w roku 2007, jak i w roku 2016 w regionie Azji Wschodniej istniało dwóch zdecydowanych liderów: Singapur oraz Hongkong, dla których taksonomiczny miernik rozwoju osiągał wartości znacznie przekraczające wyniki osiągane przez pozostałe kraje. Ponadto należy zauważyć, że w przypadku obu państw rezultat osiągnięty w roku 2016 jest lepszy niż w roku 2007, co świadczy o rozwoju społeczno-gospodarczym tych państw w analizowanym okresie. Wartość taksonomicznego miernika rozwoju (di) dla Singapuru wyniosła w 2007 roku - 0,5902, tymczasem w 2016 roku - 0,6057. Z kolei wartość di dla Hongkongu wyniosła w 2007 roku - 0,5061, a w 2016 roku - 0,5283.

Podobnie jak w przypadku krajów najwyżej rozwiniętych niezmienne w analizowanych okresach pozostały pozycje dwóch najsłabiej rozwiniętych krajów regionu, czyli Mjanmy oraz Timoru Wschodniego. Niepokojący jest fakt, że oba kraje osiągnęły w 2016 roku słabszy wynik niż w roku 2007. Nie oznacza to jednak, że państwa te nie rozwijają się społecznie i gospodarczo, lecz że rozwijają się znacznie wolniej od krajów wysoko rozwiniętych w ich regionie. Rośnie bowiem ich odległość euklidesowa od kraju modelowego (wzorcowego).

Na pozostałych miejscach w czasie badanej dekady nastąpiły znaczne zmiany. Z szóstej na trzecią pozycję awansowała Japonia, poprawiając swój wynik o ok. 20\%, z siódmej na czwartą pozycję awansowała Tajlandia (wzrost wartości miernika $d_{i}$ o ok. 18\%), z dziewiątej na szóstą pozycję awansował Wietnam, notu- 
jąc wzrost wskaźnika o ok. 38\%, a z czternastej na dziesiątą Kambodża (poprawa $d_{i}$ o niemal $35 \%$ ). Tymczasem największy spadek w rankingu zanotowały Malezja oraz Chiny. Malezja przesunęła się z miejsca trzeciego w 2007 roku na siódme w 2016 roku, uzyskując wynik niższy jedynie o ok. 4,2\%, natomiast Chiny z czwartego na ósme, uzyskując rezultat gorszy o ok. $9 \%$.

Zaskoczeniem może być stosunkowo słaby wynik Brunei, które ze względu na posiadane złoża ropy naftowej i gazu ziemnego zaliczane jest do grona krajów wysoko rozwiniętych gospodarczo. Jednakże należy pamiętać, że taksonomiczny wskaźnik rozwoju opracowany został na podstawie kilkunastu różnych cech. Założeniem tej metody jest przypisanie jednakowych wag wszystkim zmiennym diagnostycznym. Wysoki poziom PKB per capita nie zrekompensuje zatem w dużej mierze niskiej dynamiki wzrostu PKB, jaką zaobserwować można w ostatnim czasie w tym kraju. Zgodnie z przewidywaniami naukowców stopniowe wyczerpywanie złóż surowców może za kilkanaście, kilkadziesiąt lat spowodować znaczne kłopoty gospodarcze Brunei. Tym samym coraz częściej podejmowane są tam działania mające na celu aktywizację innych sektorów gospodarki, co już teraz przekłada się na spowolnienie gospodarcze w porównaniu z wynikami, jakie kraj ten osiągał w drugiej połowie XX wieku' ${ }^{1}$.

Analizując wyniki przeprowadzonego badania, nie można pominąć znacznych różnic w wartościach miernika obliczonego dla krajów Azji Wschodniej. Różnice te są odzwierciedleniem ogromnych dysproporcji w rozwoju społeczno-gospodarczym państw z tego regionu. Co więcej, jak zostało udowodnione, m.in. na przykładach wspomnianych wcześniej Mjanmy oraz Timoru Wschodniego, wraz z upływem lat dysproporcje te się powiększają.

\section{Zakończenie}

Do szeroko rozumianego regionu Azji Wschodniej zalicza się kraje znajdujące się obecnie na bardzo różnym poziomie rozwoju społeczno-gospodarczego. Z jednej strony znajdują się tu bowiem takie państwa jak: Singapur, Hongkong, Japonia, Korea Południowa czy Chiny zaliczane do grona najwyżej rozwiniętych i najbardziej liczących się gospodarek na arenie międzynarodowej. $Z$ drugiej strony są zaś takie państwa, jak: Timor Wschodni, Mjanma, Laos czy Mongolia - kraje zaliczane do grona najsłabiej rozwijających się na świecie. Znajduje to swoje odzwierciedlenie w wynikach przeprowadzonej analizy. Badanie miało na celu ustalenie poziomu rozwoju społeczno-gospodarczego krajów Azji Wschodniej przy wykorzystaniu taksonomicznego miernika rozwoju Hellwiga. Miara ta ma wiele zalet, do których bez wątpienia zaliczyć można jej kompleksowość - w badaniu wykorzystano dużą liczbę zmiennych diagnostycznych opisujących analizowane zjawisko. Jej najwięk-

${ }^{1}$ Informacje ekonomiczne nt. Brunei Darussalam, http://www.kualalumpur.msz.gov.pl/pl/infor macje_ekonomiczne/informacje_ekonomiczne_brunei/?printMode=true (04.03.2018). 
szą wadą jest jednak całkowita dowolność w kwestii doboru przez autora cech wykorzystywanych do konstrukcji miernika. Oznacza to zatem, że wyniki badania przeprowadzonego przez różnych autorów dla tej samej gospodarki i tego samego okresu badawczego mogą się znacznie różnić. Stąd najważniejszym etapem konstrukcji tego wskaźnika jest dobór zmiennych diagnostycznych poprzedzony krytycznym przeglądem literatury odnoszącej się do badanego zjawiska.

Pomimo wskazanych problemów i ograniczeń w zastosowaniu niniejszej metody badawczej kompleksowa analiza poziomu społeczno-gospodarczego krajów jest cennym źródłem informacji dla celów prowadzenia efektywnej polityki ekonomicznej w skali gospodarek narodowych oraz współpracy w ramach regionu. Pozwala bowiem na śledzenie efektów zmian dokonywanych w kierunkach rozwoju danych rodzajów polityk i porównanie osiąganych wyników z najważniejszymi partnerami i rywalami w stosunkach międzynarodowych.

\section{Literatura}

Hellwig Z., 1968, Zastosowanie metody taksonomicznej do typologicznego podziału krajów ze względu na poziom ich rozwoju i strukturę wykwalifikowanych kadr, Przegląd Statystyczny nr 4.

https://countryeconomy.com/.

https://www.indexmundi.com/.

Human Development Data, UNDP, http://hdr.undp.org/en/data.

Informacje ekonomiczne nt. Brunei Darussalam, http://www.kualalumpur.msz.gov.pl/pl/informacje ekonomiczne/informacje_ekonomiczne_brunei/?printMode=true.

Obrębalski M., 2006, Mierniki rozwoju regionalnego, [w:] D. Strahl, Metody oceny rozwoju regionalnego, AE we Wrocławiu, Wrocław.

Panek T. (red.), 2007, Statystyka społeczna, PWE, Warszawa.

Stec M., 2011, Uwarunkowania rozwojowe województw w Polsce - analiza statystyczno-ekonometryczna, [w:] Nierówności społeczne a wzrost gospodarczy. Uwarunkowania sprawnego działania w przedsiębiorstwie i regionie, Zeszyt nr 20, Wyd. UR w Rzeszowie, Rzeszów.

The World Factbook 2007, 2008, 2016, 2017, CIA, https:/www.cia.gov/library/publica tions/theworld-factbook/.

United Nations Data, http://data.un.org/.

Wasilewska E., 2011, Statystyka opisowa od podstaw. Podręcznik z zadaniami, Wyd. SGGW, Warszawa.

World Development Indicators, The World Bank, https://data.worldbank.org/indicator. 